\title{
Lymphocyte subpopulations and antibody levels in immunized malnourished children
}

\author{
BY L. S. SALIMONU', A. O. K. JOHNSON ${ }^{2}$, A. I. O. WILLIAMS', \\ G. IY ABO ADELEYE ${ }^{3}$ AND B. O. OSUNKOYA ${ }^{1}$ \\ Departments of Chemical Pathology ${ }^{1}$ (Immunology Unit), ${ }^{2}$ Paediatrics and \\ ${ }^{3}$ General Out-Patients, University College Hospital, Ibadan, Nigeria
}

(Received 21 August 1981-Accepted 12 February 1982)

\begin{abstract}
1. The proportions of lymphocyte subpopulations (by rosette tests) and the serum antibody levels (using haemagglutination techniques) were estimated in malnourished and well fed Nigerian children before and up to $21 \mathrm{~d}$ after immunization with tetanus toxoid or measles virus vaccine.

2. Significantly diminished $(P<0.01)$ mean percentage $T$ lymphocyte levels and considerably higher mean percentage null cell levels were observed in the malnourished children before immunization with either of the vaccines.

3. There was comparable in vivo increases in percentage $\mathrm{T}$ lymphocytes in malnourished and control children following the administration of each antigen.

4. The mean percentage B lymphocyte levels were similar in the control and malnourished children before and after the immunization.

5. There was a slight depression in the tetanus antibody levels $(P>0.2)$ but a significant diminution $(P<0.01)$ in measles virus antibody concentrations in the malnourished children.

6. Rise in mean percentage $T$ lymphocytes corresponded with the elevation in mean tetanus antibody levels in both malnourished and control children following tetanus toxoid immunization. This was however not the situation in the malnourished children following immunization with measles virus.

7. The observed depressed $\mathrm{T}$ lymphocyte number in malnourished children may in practice affect their handling of antigens such as measles virus in vivo.
\end{abstract}

Diminished mean percentage of circulating thymus-derived lymphocyte subpopulations had been reported in malnourished children by several workers (Chandra, 1974 a; Ferguson et al. 1974; Chandra, 1977; Neumann et al. 1977). Recently we observed in our laboratory that sheep erythrocyte $(E)$ rosette formation by lymphocytes is inhibited by sera from a considerable percentage of malnourished children (Salimonu, 1980; Salimonu \& Osunkoya, 1980; Salimonu et al. 1982). This might be one of the factors responsible for the low $T$ lymphocyte and correspondingly high null cell levels that have been reported in proteinenergy malnutrition (Chandra, 1977). In addition, in vitro stimulations of lymphocytes of healthy donors by mitogens and antigens are inhibited by sera from malnourished children (Chandra, 1974b; Heyworth et al. 1975). In the present study we determined the proportions of circulating lymphocyte subpopulations in malnourished children before and after the administration of tetanus toxoid or measles virus antigen to investigate whether peripheral blood $\mathrm{T}$ lymphocyte levels remain diminished in vivo in protein-energy malnutrition after bacterial or viral antigenic challenges.

As it is also well established in experimental animals that humoral immune responses to several antigens are thymus lymphocyte dependent (Taylor \& Wortis, 1968; Unanue, 1970; Basten \& Howard, 1973; Klaus \& Cross, 1974; Dresser \& Tao, 1975), the present study was also to investigate whether increases or decreases in the percentage of $\mathrm{T}$ lymphocytes corresponded with rise or fall in the antibody levels following antigenic challenges in both the malnourished and well fed children. 


\section{EXPERIMENTAL}

\section{Description of subjects}

The investigations on tetanus toxoid immunizations were performed on forty-five malnourished Nigerian children comprising sixteen children with marasmus, twenty with kwashiorkor and nine with marasmic-kwashiorkor aged 1-4 years. Eighteen well nourished children of the same age group served as controls. The measles virus immunization study was performed on another set of fifteen children with kwashiorkor and fifteen well-fed (control) children. Children with marasmus or marasmic-kwashiorkor were not included in the latter study because of lack of suitable (uninfected) patients at the period of study.

The malnourished children came mainly from low socio-economic families of Ibadan and environs to the General Out Patient Clinic from where they were referred to the Paediatric Nutrition Clinic both at the University College Hospital, Ibadan, Nigeria. The diagnosis was based on accepted criteria of growth failure, muscle wasting and, in the cases of kwashiorkor and marasmic-kwashiorkor, there was oedema, apathy and characteristic skin and hair changes (Lancet, 1970). The percentage weights for age ranged between $67-80 \%$ for the children with kwashiorkor, $45-65 \%$ for the marasmic-kwashiorkor children and $47-70 \%$ for the marasmic children. The control and malnourished children were from the same community. The control children were attending the same Paediatric Clinic for minor ailments or were admitted to the ward for minor surgical procedures such as release of burns contractures, herniorrhaphy and correction of urogenital anomalies such as hypospadias. There was no evidence of an overt infection in any of the malnourished and control children at the time of the study.

Children who received tetanus toxoid vaccination within the last 6 months previous to the time of the investigation were not included in the study. Each child for tetanus toxoid study received a single subcutaneous injection of $0.5 \mathrm{ml}$ alum-precipitated tetanus toxoid vaccine (10 Lf units per dose; supplied by The Lister Institute, Elstree, England) on day 0.

None of the children for measles virus vaccination had any past history of measles virus infection. Children who had received live attenuated measles virus vaccine within the last 6 months were excluded from the studies. Each child received one dose of attenuated measles virus vaccine (Merck, Sharp and Dohme, USA) subcutaneously.

\section{Blood samples}

Blood (15 ml) was collected from each malnourished or control child before immunization, and at 3,10 and $21 \mathrm{~d}$ after immunization. From each collection, a $5 \mathrm{ml}$ portion was allowed to clot, the serum was separated and stored at $-20^{\circ}$ until analysed for antibody titres. For the estimations of $\mathrm{T}$ and $\mathrm{B}$ lymphocytes the remaining $10 \mathrm{ml}$ was collected in heparinized bottles.

\section{Method of analysis}

The indirect haemagglutination method of Stavitsky (1954) was employed to estimate the tetanus antibody levels whilst measles antibody levels were quantified by the haemagglutination inhibition technique of Sever (1962). T and B lymphocytes were estimated by the method of Jondal et al. (1972). The null cells were obtained by difference between total percent lymphocytes and the sum of the $T$ and $B$ lymphocytes.

The Student's $t$ test or paired $t$ test was employed to test the significance of the differences between means. 
Table 1. Increases in percentage T lymphocytes following tetanus toxoid immunization of malnourished Nigerian children

(Mean values with their standard deviations; values in parentheses are increases in mean $\pm 1 \mathrm{SD}$ of percentage $T$ lymphocytes)

\begin{tabular}{|c|c|c|c|c|c|c|c|c|}
\hline & & & \multicolumn{6}{|c|}{ Days post immunization } \\
\hline & \multicolumn{2}{|c|}{ Pre-immune } & \multicolumn{2}{|c|}{3} & \multicolumn{2}{|c|}{10} & \multicolumn{2}{|c|}{21} \\
\hline & Mean & SD & Mean & SD & Mean & SD & Mean & SD \\
\hline Group controls & 42 & 10 & 53 & $\begin{array}{c}12 \\
(11+5)\end{array}$ & 57 & $\begin{array}{c}10 \\
(15 \pm 5)\end{array}$ & 47 & $\begin{array}{c}11 \\
(5 \pm 3)\end{array}$ \\
\hline Marasmus & 25 & 6 & 34 & $\begin{array}{c}11 \\
(9 \pm 3)\end{array}$ & 39 & $\begin{array}{c}1 \overline{3} \\
(14 \pm 6)\end{array}$ & 33 & $\begin{array}{c}12 \\
(8 \pm 5)\end{array}$ \\
\hline Kwashiorkor & 21 & 99 & 29 & $\begin{array}{c}10 \\
(8 \pm 5)\end{array}$ & 35 & $\begin{array}{c}10 \\
(14 \pm 4)\end{array}$ & 27 & $\begin{array}{c}7 \\
(6 \pm 3)\end{array}$ \\
\hline Marasmic-kwashiorkor & 14 & 8 & 21 & $\begin{array}{c}9 \\
(7 \pm 5)\end{array}$ & 26 & $\begin{array}{c}14 \\
(12 \pm 6)\end{array}$ & 19 & $\begin{array}{c}10 \\
(5 \pm 3)\end{array}$ \\
\hline \multicolumn{9}{|l|}{ Comparing the mean values: } \\
\hline Controls $v$. marasmus & \multicolumn{2}{|c|}{$P<0.01$} & \multirow{2}{*}{\multicolumn{2}{|c|}{$<0.01$}} & \multirow{2}{*}{\multicolumn{2}{|c|}{$<0.01$}} & \multicolumn{2}{|c|}{$<0.01$} \\
\hline Controls $v$. kwashiorkor & \multicolumn{2}{|c|}{$P<0.01$} & $<0.01$ & & & & \multirow{2}{*}{\multicolumn{2}{|c|}{$\begin{array}{l}<0.01 \\
<0.01\end{array}$}} \\
\hline Controls $v$. marasmic-kwashiorkor & \multicolumn{2}{|c|}{$P<0.01$} & \multicolumn{2}{|c|}{$<0.01$} & \multicolumn{2}{|c|}{$\begin{array}{l}<0.01 \\
<0.01\end{array}$} & & \\
\hline \multicolumn{5}{|l|}{ Comparing the differences in values: } & & \\
\hline Controls $v$. marasmus & $P$ & - & \multicolumn{2}{|c|}{$>0.1(\mathrm{NS})$} & \multicolumn{2}{|c|}{$>0.2(\mathrm{NS})$} & \multicolumn{2}{|c|}{$<0.05$} \\
\hline Controls $v$. kwashiorkor & $P$ & - & \multicolumn{2}{|c|}{$<0.1$ (NS) } & \multicolumn{2}{|c|}{$>0.2(\mathrm{NS})$} & \multirow{2}{*}{\multicolumn{2}{|c|}{$>0.2$ (NS) }} \\
\hline Controls $v$. marasmic-kwashiorkor & $P$ & - & \multicolumn{2}{|c|}{$>0.1(\mathrm{NS})$} & \multicolumn{2}{|c|}{$>0.2(\mathrm{NS})$} & & \\
\hline
\end{tabular}

NS, not significant.

\section{Ethical considerations}

This study gave the opportunity for active immunization of children at risk, as tetanus and measles are two of the most common infections contributing to the high morbidity and mortality in children from developing countries.

Blood specimens for this study were always taken with other blood specimens required for essential investigations, e.g. full blood count, serum proteins and electrolytes, for the proper management of the malnourished children. The parents or guardians of the well-fed control children were told of the importance of active immunizations and their consent obtained for the ensuing blood studies.

The ethical committee of the Department of Paediatrics of the University College Hospital, Ibadan approved the protocol for the study of the immune system in malnourished children.

\section{RESULTS}

\section{Studies with tetanus toxoid}

Mean percentage T lymphocytes were considerably higher $(P<0.01)$ in the control group than in the marasmic group before and up to $21 \mathrm{~d}$ (inclusive) after immunization with tetanus toxoid (Table 1). In the children with kwashiorkor and marasmic-kwashiorkor, the significant diminution in mean percentage $T$ lymphocyte concentrations persisted throughout the time of study. There were considerable post-immunization increases in the mean percentage $\mathrm{T}$ lymphocyte concentrations of both the control and each of the different malnourished groups up to $10 \mathrm{~d}$, after which the mean levels dropped. The B lymphocyte levels were similar in the control and in each of the malnourished groups (Table 2) before 
Table 2. Mean percentage $B$ lymphocytes following tetanus toxoid immunization of the malnourished Nigerian children

(Mean values with their standard deviations)

\begin{tabular}{|c|c|c|c|c|c|c|c|c|}
\hline & & & \multicolumn{6}{|c|}{ Days post immunization } \\
\hline & \multicolumn{2}{|c|}{ Pre-immune } & \multicolumn{2}{|c|}{3} & \multicolumn{2}{|c|}{10} & \multicolumn{2}{|c|}{21} \\
\hline & Mean & $\mathrm{SD}$ & Mean & SD & Mean & SD & Mean & SD \\
\hline Group controls & 14 & 5 & 16 & 5 & 17 & 5 & 18 & 6 \\
\hline Marasmus & 12 & 5 & 12 & 4 & 14 & 5 & 16 & 4 \\
\hline Kwashiorkor & 11 & 4 & 12 & 6 & 14 & 6 & 16 & 6 \\
\hline Marasmic-kwashiorkor & 11 & 6 & 11 & 5 & 14 & 8 & 15 & 6 \\
\hline \multicolumn{9}{|l|}{ Comparing the mean values: } \\
\hline Controls $v$. marasmus & \multicolumn{2}{|c|}{$P>0.2(\mathrm{NS})$} & \multicolumn{2}{|c|}{$>0.2$ (NS) } & \multicolumn{2}{|c|}{$>0.2(\mathrm{NS})$} & \multicolumn{2}{|c|}{$>0.2(\mathrm{NS})$} \\
\hline Controls v. kwashiorkor & \multicolumn{2}{|c|}{$P<0.1$ (NS) } & \multicolumn{2}{|c|}{$<0.1$ (NS) } & \multicolumn{2}{|c|}{$>0.2(\mathrm{NS})$} & \multicolumn{2}{|c|}{$>0.2(\mathrm{NS})$} \\
\hline Controls $v$. marasmic-kwashiorkor & \multicolumn{2}{|c|}{$P>0.2(\mathrm{NS})$} & \multicolumn{2}{|c|}{$<0.1$ (NS) } & \multicolumn{2}{|c|}{$>0.2(\mathrm{NS})$} & \multicolumn{2}{|c|}{$>0.2(\mathrm{NS})$} \\
\hline
\end{tabular}

NS, not significant.

Table 3. Increases in tetanus haemagglutinating antibody titres following tetanus toxoid immunization of malnourished Nigerian children

(Mean values with their standard deviations; values in parentheses are increases in mean tetanus antibody titres)

\begin{tabular}{|c|c|c|c|c|c|c|c|c|}
\hline & & & \multicolumn{6}{|c|}{ Days post immunization } \\
\hline & \multicolumn{2}{|c|}{ Pre-immune } & \multicolumn{2}{|c|}{3} & \multicolumn{2}{|c|}{10} & \multicolumn{2}{|c|}{21} \\
\hline & Mean & SD & Mean & SD & Mean & SD & Mean & SD \\
\hline Group controls & 311 & 186 & 1102 & $\begin{array}{c}315 \\
(791)\end{array}$ & 2880 & $\begin{array}{r}774 \\
(2569)\end{array}$ & 2560 & $\begin{array}{c}707 \\
(2249)\end{array}$ \\
\hline Marasmus & 311 & 281 & 960 & $\begin{array}{c}331 \\
(649)\end{array}$ & 2276 & $\begin{array}{c}793 \\
(1965)\end{array}$ & 2468 & $\begin{array}{r}716 \\
(2158)\end{array}$ \\
\hline Kwashiorkor & 290 & 200 & 823 & $\begin{array}{c}302 \\
(533)\end{array}$ & 2240 & $\begin{array}{c}630 \\
(1950)\end{array}$ & 2080 & $\begin{array}{r}467 \\
(1790)\end{array}$ \\
\hline Marasmic-kwashiorkor & 289 & 224 & 800 & $\begin{array}{c}213 \\
(511)\end{array}$ & 2048 & $\begin{array}{c}535 \\
(1759)\end{array}$ & 1920 & $\begin{array}{c}458 \\
(1631)\end{array}$ \\
\hline \multicolumn{9}{|l|}{ Comparing the mean values: } \\
\hline Controls $v$. marasmus & \multirow{3}{*}{\multicolumn{2}{|c|}{$\begin{array}{l}P>0.2(\mathrm{NS}) \\
P>0.2(\mathrm{NS}) \\
P>0.2(\mathrm{NS})\end{array}$}} & \multirow{3}{*}{\multicolumn{2}{|c|}{$\begin{array}{l}>0.2(\mathrm{NS}) \\
>0.2(\mathrm{NS}) \\
>0.2(\mathrm{NS})\end{array}$}} & \multirow{3}{*}{\multicolumn{2}{|c|}{$\begin{array}{l}>0.2(\mathrm{NS}) \\
>0.2(\mathrm{NS}) \\
>0.2(\mathrm{NS})\end{array}$}} & \multirow{3}{*}{\multicolumn{2}{|c|}{$\begin{array}{l}>0.2(\mathrm{NS}) \\
>0.2(\mathrm{NS}) \\
>0.2(\mathrm{NS})\end{array}$}} \\
\hline Controls $v$. kwashiorkor & & & & & & & & \\
\hline Controls $v$. marasmic-kwashiorkor & & & & & & & & \\
\hline
\end{tabular}

NS, not significant.

and after tetanus toxoid immunization. The mean percentage null cells were significantly less in the control children than the malnourished children throughout the period of study. The mean pre-immunization percentage null cell levels were highest in each of the groups. After tetanus toxoid administration there was a progressive reduction in this value with time reaching its lowest by day 10 .

The pre-immune mean concentrations of tetanus antibody were similar in each of the malnourished groups and in the control groups (Table 3 ). The mean antibody concentrations 
Table 4. Increases in percentage T lymphocytes following measles virus immunization of malnourished Nigerian children

(Mean values with their standard deviations; values in parentheses are increases in mean \pm 1 SD of percentage $\mathrm{T}$ lymphocytes)

\begin{tabular}{|c|c|c|c|c|c|c|c|c|}
\hline & & & \multicolumn{6}{|c|}{ Days post immunization } \\
\hline & \multicolumn{2}{|c|}{ Pre-immune } & \multicolumn{2}{|c|}{3} & \multicolumn{2}{|c|}{10} & \multicolumn{2}{|c|}{21} \\
\hline & Mean & SD & Mean & SD & Mean & SD & Mean & SD \\
\hline Group controls & 45 & 10 & 50 & $\begin{array}{c}8 \\
(5+5)\end{array}$ & 60 & $\begin{array}{c}11 \\
(15 \pm 4)\end{array}$ & 48 & $\begin{array}{c}9 \\
(3+3)\end{array}$ \\
\hline Kwashiorkor & 22 & 11 & 31 & $\begin{array}{c}15 \\
(9 \pm 8)\end{array}$ & 43 & $\begin{array}{c}18 \\
(21 \pm 12)\end{array}$ & 39 & $\begin{array}{c}12 \\
(17 \pm 10)\end{array}$ \\
\hline $\begin{array}{l}\text { Comparing the mean values: } \\
\text { Controls } v \text {. kwashiorkor } \\
\text { Comparing differences } \\
\text { in values: }\end{array}$ & \multicolumn{2}{|c|}{$P<0.01$} & \multicolumn{2}{|c|}{$<0.01$} & \multicolumn{2}{|c|}{$<0.05$} & \multicolumn{2}{|c|}{$>0.2(\mathrm{NS})$} \\
\hline Controls $v$. kwashiorkor & $P$ & - & & 1 (NS) & & $\cdot 1$ (NS) & & 01 \\
\hline
\end{tabular}

NS, not significant.

Table 5. Mean percentage B lymphocytes following measles virus immunization of malnourished Nigerian children

(Mean values with their standard deviations)

\begin{tabular}{|c|c|c|c|c|c|c|c|c|}
\hline & & & \multicolumn{6}{|c|}{ Days post immunization } \\
\hline & \multicolumn{2}{|c|}{ Pre-immune } & \multicolumn{2}{|c|}{3} & \multicolumn{2}{|c|}{10} & \multicolumn{2}{|c|}{21} \\
\hline & Mean & SD & Mean & SD & Mean & SD & Mean & SD \\
\hline Group controls & 13 & 6 & 13 & 7 & 15 & 5 & 15 & 7 \\
\hline Kwashiorkor & 12 & 6 & 13 & 7 & 14 & 6 & 14 & 8 \\
\hline $\begin{array}{l}\text { Comparing the mean values: } \\
\text { Controls } v \text {. kwashiorkor }\end{array}$ & \multicolumn{2}{|c|}{$P>0.2(\mathrm{NS})$} & \multicolumn{2}{|c|}{$>0.2(\mathrm{NS})$} & \multicolumn{2}{|c|}{$>0.2(\mathrm{NS})$} & \multicolumn{2}{|c|}{$>0.2(\mathrm{NS}$} \\
\hline
\end{tabular}

NS, not significant.

increased progressively with time after the vaccination. The control group had the highest elevations of mean levels after the immunization, followed by the groups with marasmus and kwashiorkor. Children with marasmic-kwashiorkor had the lowest. There was however no statistical variation in the mean antibody levels between each of the malnourished groups and the control group throughout the period of study $(P>0 \cdot 2)$.

The difference between the mean post immunization and the mean pre-immune antibody titres gave the increases in mean tetanus antibody titres (Table 3).

\section{Studies with measles virus vaccine}

The mean percentage $T$ lymphocyte levels were diminished in children with kwashiorkor before measles virus vaccination. The levels increased gradually up to $10 \mathrm{~d}$ in both the children with kwashiorkor and in the control children. The rise became substantial on day 10 in both groups (Table 4). As previously observed in the study with tetanus toxoid, the 
Table 6. Increases in measles haemagglutinating antibody titres following measles virus immunization of Nigerian malnourished children

(Mean values with their standard deviations; values in parentheses are increases in mean measles antibody titres)

\begin{tabular}{|c|c|c|c|c|c|c|c|c|}
\hline & & & \multicolumn{6}{|c|}{ Days post immunization } \\
\hline & \multicolumn{2}{|c|}{ Pre-immune } & \multicolumn{2}{|c|}{3} & \multicolumn{2}{|c|}{10} & \multicolumn{2}{|c|}{21} \\
\hline & Mean & $\mathrm{SD}$ & Mean & $\mathrm{SD}$ & Mean & SD & Mean & SD \\
\hline Group controls & $10 \cdot 5$ & 10 & 17 & $\begin{array}{l}9 \cdot 8 \\
(6 \cdot 8)\end{array}$ & $52 \cdot 6$ & $\begin{array}{c}37 \cdot 7 \\
(42 \cdot 2)\end{array}$ & $69 \cdot 3$ & $\begin{array}{c}31 \cdot 5 \\
(58 \cdot 8)\end{array}$ \\
\hline Kwashiorkor & $10 \cdot 7$ & $8 \cdot 0$ & $14 \cdot 5$ & $\begin{array}{l}9.3 \\
(3.8)\end{array}$ & $17 \cdot 0$ & $\begin{array}{l}6 \cdot 5 \\
(6 \cdot 3)\end{array}$ & $25 \cdot 7$ & $\begin{array}{l}19 \cdot 5 \\
(15)\end{array}$ \\
\hline $\begin{array}{l}\text { Comparing the mean values: } \\
\text { Controls } v \text {. kwashiorkor }\end{array}$ & \multicolumn{2}{|c|}{$P>0.2(\mathrm{NS})$} & \multicolumn{2}{|c|}{$>0.2(\mathrm{NS})$} & \multicolumn{2}{|c|}{$<0.05$} & \multicolumn{2}{|c|}{$<0.01$} \\
\hline
\end{tabular}

NS, not significant.

children with kwashiorkor were not different from the control children in the proportion of circulating B lymphocytes. The pre-immune levels showed only negligible rise after the administration of the antigen (Table 5). The mean percentage of null cells was higher in the children with kwashiorkor before measles virus immunization. The levels decreased with time in the two study populations, reaching its lowest by day 10 .

There was no significant difference in the pre-immune mean measles antibody levels between the control and the children with kwashiorkor studied $(P>0.2$; Table 6$)$. Antibody formation following measles virus vaccination however, was depressed in the children with kwashiorkor. This reduction in antibody levels became noticeable on days 10 and 21.

\section{DISCUSSION}

Diminished mean percentage of circulating thymus-derived (T) lymphocyte subpopulations in malnourished children previously reported by several workers (Chandra, 1974a; Neumann et al. 1977) were confirmed in the present study. We also observed increases in the percentage of circulating $\mathrm{T}$ lymphocytes in the malnourished and control children after the administration of tetanus toxoid or measles virus antigen.

Our present observations of insignificant dimunition in tetanus antibody levels in malnourished children after the administration of tetanus toxoid confirm previous findings of Chandra (1972). Significantly impaired measles virus haemagglutinating antibody production by malnourished children reported in this study was also demonstrated by Hafez et al. (1977).

It is surprising that the B lymphocytes did not show any appreciable changes throughout the $21 \mathrm{~d}$ period of the investigations in both the malnourished and control children. In a previous study in healthy adults, Chollet $e t$ al. (1979) also observed a slight but insignificant decrease in the $B$ cell percentage $3 \mathrm{~d}$ post tetanus toxoid immunization. In the present study there were no significant differences in the mean percentage subpopulation of $B$ cells between the control and malnourished children before and after the immunizations.

Our results show that there is comparable in vivo increase in $T$ lymphocyte numbers in children with protein-energy malnutrition as well as controls after stimulation by tetanus toxoid and measles virus antigens (even though the absolute percentage was still significantly 
depressed as a result of very low pre-immune level). This suggests that the sera of malnourished children do not prevent the in vivo stimulation of $T$ lymphocytes by these antigens which is contrary to previous findings in in vitro studies where presence of sera from malnourished children was observed to inhibit stimulations of $\mathrm{T}$ lymphocytes of healthy donors by mitogens and antigens (Chandra, 1974b; Heyworth et al. 1975). Reasons for these different observations can only be speculative. It is possible that in vivo, tetanus toxoid and measles virus antigens are more potent than the mitogens (phytohaemagglutinin) and antigens (leucocytes) that were employed in the in vitro experiments. Differences between the conditions in vivo and in vitro and also in the techniques of assay; variations in time lag between lymphocyte challenge and analysis of percentage $T$ lymphocytes and the likely reduction in the serum level of the inhibitory substance as a result of the malnourished children's management (in the present study) may be some of the factors responsible for variations between the in vivo and in vitro findings.

Furthermore, it was previously demonstrated by us (Salimonu \& Osunkoya, 1980; Salimonu et al. 1982) that the sera of a considerable number of children having protein-energy malnutrition contain an inhibitor of sheep erythrocyte (E) rosette formation. From our findings in the same study, we postulated that it appeared that the sheep erythrocyte receptors on some of the $T$ lymphocytes of such children adsorb an inhibitory substance in vivo making them unreactive with sheep erythrocytes in vitro. Such $T$ lymphocytes would therefore be recorded as null cells (Salimonu \& Osunkoya, 1980; Salimonu et al. 1982). We also suggested in the latter study that attachments of $T$ lymphocytes in vitro by an inhibitory substance from sera of malnourished children might be responsible for the observed inhibition of $\mathrm{T}$ lymphocyte stimulation by mitogens and antigens in vitro. The present study however suggests that such attachment of an inhibitory substance on $T$ lymphocytes in vivo does not affect their stimulation by tetanus toxoid or measles virus antigen. It is quite possible however that despite the inhibition of some of the lymphocytes because of the attachment, the few $T$ lymphocytes having no attachments were highly responsive to tetanus toxoid or measles virus antigen stimulation. This second proposition is however less likely.

The observed significant depression in circulating $\mathrm{T}$ lymphocyte numbers and functions also affecting the humoral immune responses in measles vaccination might predispose such malnourished children to persistent infections, a situation that has been documented by several workers (Trowell, 1949; Williams, 1953; Gandra \& Scrimshaw, 1961 ; Morley, 1969; Sengar \& Terasaki, 1971; Gotoff, 1973). Our observations in the present studies of defects in the humoral responses to viral antigen stimulation in malnourished children may also be the result of defective $T$ and $B$ cell co-operation. The need for such a co-operation by most antigens as well as the variations in strength of these antigens might explain the several inconsistent reports on the humoral immune responses of malnourished children and other protein depleted experimental animals to many antigens (Olarte et al. 1956; Scrimshaw \& Behar, 1961; Hodges et al. 1962; McFarlane et al. 1970; Chandra, 1975; Hafez et al. 1977).

In conclusion, the differences we observed in the apparent immune competence between well fed and malnourished children in this study provides clear evidence that the depressed cell mediated immunity in malnutrition is important when it comes to the handling of such antigens as measles virus in vivo.

The authors are grateful to Messrs Bayo Oyelami and S. O. Odunuga for their technical assistance. The study was financed by the University of Ibadan Senate Research Grant No. 2/SRG3/29 awarded to L.S.S. 


\section{REFERENCES}

Basten, A. \& Howard, J. G. (1973). Contemporary Topics in Immunology, vol. 2, p. 265 [A. J. S. Davies and R. L. Caster, editors]. New York: Plenum Press.

Chandra, R. K. (1972). J. Pediat 81, 194.

Chandra, R. K. (1974a). Br. med. J. iii, 608.

Chandra, R. K. (1974b). In Progress in Immunology II, vol. 4, p. 355 [L. Brent and J. Holborrow editors]. Amsterdam: North Holland.

Chandra, R. K. (1975). Br. med. J. ii, 583.

Chandra, R. K. (1977). Paediatrics, Springfield 59, 423.

Chollet, P. H., Chassagne, J., Phillipe, P., Vuillaume, C., Maublant, J., Gauvin, H., Rey, M. \& Plagne, R. (1979). Clin. exp. Immun. 37, 152.

Dresser, D. W. \& Tao, T. W. (1975). Immunology 28, 443.

Ferguson, A. C., Lawlor, C. J., Neumann, C. G., Oh, W. \& Stiehm, E. R. (1974). J. Pediat. $85,717$.

Gandra, Y. R. \& Scrimshaw, N. S. (1961). Am. J. clin. Nutr. 9, 159.

Gotoff, S. P. (1973). In Immunologic Disorders in Infants and Children, p. 321 [E. R. Stiehm and V. A. Fulginiti, editors]. Philadelphia: W. B. Saunders.

Hafez, M., Aref, G. H., Mahareb, S. W., Kassem, A. S., El Tahhan, H., Rizk, Z., Mahfonz, R. \& Saad, K. (1977). J. trop. Med. Hyg. 80, 36.

Heyworth, B., Moore, D. L. \& Brown, J. (1975). Clin. exp. Immun. 22, 72.

Hodges, R. E., Bean, W. N., Ohlson, M. A. \& Bleiler, R. E. (1962). Am. J. clin. Nutr. $11,187$.

Jondal, M., Holm, C. \& Wigzell, H. (1972). J. expl Med. 136, 207.

Klaus, G. G. \& Cross, A. M. (1974). Cell. Immun. 14, 226.

Lancet (1970). Lancet ii, 302.

McFarlane, H., Reddy, S., Cooke, A., Long, O., Onabamiro, M. O. \& Houba, J. E. (1970). Trop. Geog. Med. 22, 61 .

Morley, D. (1969). Br. med. J. i, 297.

Neumann, C. G., Stiehm, E. R., Swenseid, M., Ferguson, A. C. \& Lawlor, G. (1977). In Malnutrition and the Immune Response, p. 77 [R. M. Suskind, editor]. New York: Raven Press.

Olarte, J., Cravioto, J. \& Campos, B. (1956). Boln. med. Hosp. infant., Méx 13, 467.

Salimonu, L. S. (1980). Immune responses and a serum inhibitory substance in malnourished children. PhD Thesis. University of Ibadan, Nigeria.

Salimonu, L. S., Johnson, A. O. K., Williams, A. I. O., Adeleye, G. Iyabode \& Osunkoya, B. O. (1982). Clin. expl Immun. 47 (In the Press).

Salimonu, L. S. \& Osunkoya, B. O. (1980). Am. J. clin. Nutr. 33, 2699.

Scrimshaw, N. S. \& Behar, M. (1961). Science N.Y. 133, 2039.

Sengar, D. P. S. \& Terasaki, P. I. (1971). Transplantation 2, 260.

Sever, J. L. (1962). J. Immun. 88, 320.

Stavitsky, A. B. (1954). J. Immun. 72, 360.

Taylor, R. R. \& Wortis, H. H. (1968). Nature, Lond. 220, 927.

Trowell, H. C. (1949). Trans. Roy. Soc. trop. Med. Hyg. 42, 417.

Unanue, E. R. (1970). J. Immun. 105, 1339.

Williams, C. D. (1953). J. Am. med. Ass. 153, 1280 